\section{Cochlioquinones and Epi-Cochlioquinones:} Antagonists of the Human Chemokine

\section{Receptor CCR5 from Bipolaris brizae and Stachybotrys chartarum}

\author{
K. Yoganathan, ${ }^{*}$ Lay-kien Yang, Christine Rossant, ${ }^{\dagger}$ \\ Yicun Huang, Siewbee NG, Mark S. Butler \\ and ANTONy D. Buss \\ MerLion Pharmaceuticals, \\ 59A Science Park Drive, The Fleming, \\ Singapore Science Park, Singapore, 118240
}

(Received for publication October 9, 2003)

Chemokines are small proteins $(7 \sim 16 \mathrm{kDa})$ that act at $\mathrm{G}$ protein-coupled receptors to regulate a variety of physiological and pathophysiological processes ${ }^{1,2)}$. The human immunodeficiency virus Type 1 (HIV-1) principally uses CCR5 and CXCR4 chemokine receptors as coreceptors with CD4 to gain entry into target cells ${ }^{3,4)}$. Therefore, a molecule that binds to the CCR5 receptor could potentially prevent HIV-1 entry into cells, which makes CCR5 an important target for anti-HIV-1 therapy ${ }^{5)}$.

In the course of screening our extract library for inhibitors of $\mathrm{CCR}^{6,7)}$, extracts from Bipolaris brizae (Nisikado) Shoem and Stachybotrys chartarum were found to displace macrophage inflammatory protein (MIP)-1 $\alpha$ from the human chemokine receptor CCR5. Bioassay directed fractionation led to the isolation of three active cochlioquinones from Bipolaris brizae (Nisikado) Shoem, namely, 17-methoxycochlioquinone A (1), cochlioquinone A $(2)^{8 \sim 10)}$ and isocochlioquinone A $(3)^{8 \sim 10)}$. Two active epi-cochlioquinones compounds, 11-O-methyl-epicochlioquinone A (4) and epi-cochlioquinone A (5) ${ }^{11)}$, were isolated from Stachybotrys chartarum. Herein, we report the isolation, structure elucidation and biological activity of 1, 2, 3, 4 and 5 .

\section{Materials and Methods}

\section{CCR5 Assay}

CCR5 receptor binding activity was determined in a 96well scintillation proximity assay ${ }^{12)}$ (SPA) using a $\left[{ }^{125} \mathrm{I}\right]$ human MIP- $1 \alpha$ and membranes prepared from $\mathrm{CHO}$ cells over expressing the human CCR5 receptor. The samples were dissolved in $12.5 \%$ aqueous DMSO and incubated with $12 \mu \mathrm{g}$ membranes, $0.17 \mathrm{nM}\left[{ }^{125} \mathrm{I}\right]-\mathrm{MIP}-1 \alpha, 0.25 \mathrm{mg}$ Wheat Germ Agglutinin-SPA beads in assay buffer $(50 \mathrm{~mm}$ HEPES, $1 \mathrm{mM} \mathrm{CaCl}_{2}, 1 \mathrm{~mm} \mathrm{MgCl}_{2}, 1 \% \mathrm{BSA}$ and a protease inhibitor cocktail), shaking for 5 hours at room temperature. Radioactivity (total binding) was measured after a 2 hours bead settling period. Non-specific binding was defined in the presence of $1 \mu \mathrm{M}$ recombinant human MIP- $1 \alpha$.

\section{Results and Discussion}

\section{Fermentation}

The producing microorganism was identified as Bipolaris brizae (Nisikado) Shoem based on morphological characteristics. The strain has been deposited in the MerLion Pharmaceuticals culture collection as F32659. The strain was sub-cultured on malt extract agar (CM057B, Oxoid) for 7 days at $24^{\circ} \mathrm{C}$. It was used to inoculate $250 \mathrm{ml}$ Erlenmeyer flasks each containing $50 \mathrm{ml}$ of seed medium composed of $0.4 \%$ glucose, $1 \%$ malt extract and $0.4 \%$ yeast extract. The $\mathrm{pH}$ of the medium was adjusted to 5.5 prior to sterilization. The seed flasks were incubated for 5 days at $24^{\circ} \mathrm{C}$ on a rotary shaker at $200 \mathrm{rpm}$. A volume of $5 \mathrm{ml}$ of seed culture was used to inoculate $50 \mathrm{ml}$ of liquid medium in a $250 \mathrm{ml}$ flask. The liquid medium is composed of $0.4 \%$ yeast extract, $2 \%$ glucose and $2 \%$ oatmeal. The $\mathrm{pH}$ was adjusted to 7.5 and autoclaved at $121^{\circ} \mathrm{C}$ for 30 minutes. The fermentation was carried out for 9 days at $24^{\circ} \mathrm{C}$ at $200 \mathrm{rpm}$.

The second fungal strains F32923 (Stachybotrys chartarum) has been deposited in the MerLion

\footnotetext{
* Corresponding author: yoga@merlionpharma.com

† Present address: Upstate Ltd., Cowley Rd., Cambridge CB4 ODS, UK.
} 
Table 1. Physico-chemical properties of 17-methoxycochlioquinone A (1) and 11-O-methyl-epi-cochlioquinone A (4).

\begin{tabular}{|c|c|c|}
\hline & 1 & 4 \\
\hline appearance & Yellow oil & Yellow solid \\
\hline Molecular formula & $\mathrm{C}_{31} \mathrm{H}_{46} \mathrm{O}_{9}$ & $\mathrm{C}_{31} \mathrm{H}_{46} \mathrm{O}_{8}$ \\
\hline ESI-MS $(\mathrm{M}+\mathrm{Na})^{+}$ & $\begin{array}{l}\text { 585.3042(calcd } \\
585.3040)\end{array}$ & $\begin{array}{l}569.3071 \text { (calcd } \\
569.3090)\end{array}$ \\
\hline$[\alpha]_{D}^{25}$ & $\begin{array}{l}+141^{\circ}(c 0.20, \\
\left.\mathrm{CHCl}_{3}\right)\end{array}$ & $+38^{\circ}\left(c 0.12, \mathrm{CHCl}_{3}\right)$ \\
\hline $\mathrm{UV}(\mathrm{MeOH}) \lambda_{\max }(\log \varepsilon) \mathrm{nm}$ & $283(4.04), 386(3.52)$ & $270(4.04), 385(3.52)$ \\
\hline $\mathrm{IR} v_{\max }(\mathrm{NaCl}) \mathrm{cm}^{-1}$ & $\begin{array}{l}3521,2968,2879, \\
1730,1660,1645, \\
1456\end{array}$ & $\begin{array}{l}3468,2971,2936,1734, \\
1678,1645,1454\end{array}$ \\
\hline
\end{tabular}

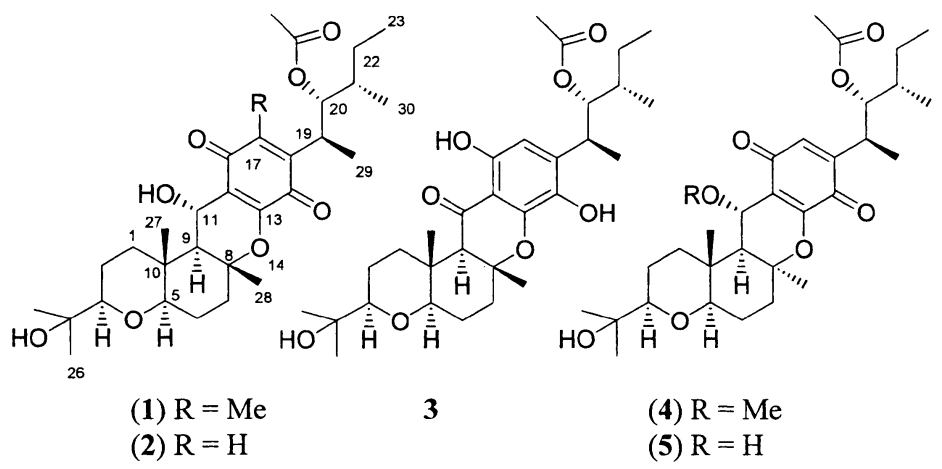

Pharmaceuticals culture collection. The strain was subcultured and fermented using the same conditions described above.

\section{Isolation of Active Constituents of Bipolaris brizae (Nisikado) Shoem}

The freeze-dried fermentation broth (2 liters) of Bipolaris brizae (Nisikado) Shoem was extracted 3 times with $\mathrm{CH}_{2} \mathrm{Cl}_{2}-\mathrm{MeOH}(1: 1)$ and evaporated to dryness under vacuum. The dry extract $(14.5 \mathrm{~g})$ was partitioned 3 times between hexane and $90 \% \mathrm{MeOH}$ in $\mathrm{H}_{2} \mathrm{O}(1: 1)$. The $90 \% \mathrm{MeOH}$ portion was adjusted to $70 \%$ with $\mathrm{H}_{2} \mathrm{O}$, and then partitioned 3 times with $\mathrm{CHCl}_{3}$. The active $\mathrm{CHCl}_{3}$ fraction $(1.7 \mathrm{~g})$ was subjected to reverse phase preparative HPLC (isocratic elution for 70 minutes; mobile phase: $0.1 \% \mathrm{HCOOH}$ in acetonitrile $+0.1 \% \mathrm{HCOOH}$ in $\mathrm{H}_{2} \mathrm{O}$ (65:35); flow rate: $10 \mathrm{ml} /$ minute) to give compounds 1 (6 mg), cochlioquinone $\mathrm{A}(2)(1 \mathrm{mg})$ and isocochlioquinone A (3) (3 mg). Cochlioquinone A (2) and isocochlioquinone A (3) were identified by comparison of their spectral properties with those reported in the literature ${ }^{8 \sim 10)}$.

\section{Isolation of Active Constituents of Stachybotrys chartarum}

The freeze-dried fermentation broth (2 liters) of Stachybotrys chartarum was extracted 3 times with $\mathrm{CH}_{2} \mathrm{Cl}_{2}-\mathrm{CH}_{3} \mathrm{OH}(1: 1)$ and evaporated to dryness under vacuum. The crude extract $(2 \mathrm{~g})$ was partitioned 3 times between hexane and $90 \% \mathrm{MeOH}$ in $\mathrm{H}_{2} \mathrm{O}(1: 1)$. The active hexane fraction $(0.5 \mathrm{~g})$ was subjected to reverse phase preparative HPLC (gradient elution; mobile phase: $0.1 \%$ $\mathrm{HCOOH}$ in acetonitrile $+0.1 \% \mathrm{HCOOH}$ in $\mathrm{H}_{2} \mathrm{O}$ ( $50: 50 \rightarrow 100: 0$ over 30 minutes); flow rate: $12 \mathrm{ml} /$ minute) to give (4) (3 mg) and epi-cochlioquinone A (5) (1 mg). Epi-cochlioquinone A (5) was identified by comparison of its spectral properties with those previously reported ${ }^{11)}$.

\section{Structure Elucidation}

The molecular formula $\left(\mathrm{C}_{31} \mathrm{H}_{46} \mathrm{O}_{9}\right)$ of compound $\mathbf{1}$ was established by analysis of the ${ }^{13} \mathrm{C}$ NMR, multiplicity-edited HSQC spectrum and positive HR-ESIMS. The physicochemical properties of $\mathbf{1}$ are given in Table 1 . The IR spectrum showed characteristic absorption bands from $\mathrm{OH}$ 
Table 2. ${ }^{1} \mathrm{H}(500 \mathrm{MHz})$ and ${ }^{13} \mathrm{C}(125 \mathrm{MHz})$ NMR data for 17 -methoxycochlioquinone $\mathrm{A}(\mathbf{1})$ in $\mathrm{CDCl}_{3}$.

\begin{tabular}{|c|c|c|c|c|c|}
\hline No. & ${ }^{13} \mathrm{C}(\delta$ & & $\begin{array}{l}{ }^{1} \mathrm{H} \delta,(\mathrm{m}, J \text { in } \\
\mathrm{Hz})\end{array}$ & COSY & $\begin{array}{l}\mathrm{HMBC} \\
{ }^{1} \mathrm{H} \text { to }{ }^{13} \mathrm{C}\end{array}$ \\
\hline 1 & 39.5 & $t$ & $\begin{array}{l}1.42 \mathrm{~m} \\
2.45 \mathrm{~m}\end{array}$ & $\begin{array}{l}1 \mathrm{~b}, 2,2 \mathrm{~b} \\
1 \mathrm{a}, 2,2 \mathrm{~b}\end{array}$ & 3,10 \\
\hline 2 & 22.5 & $\mathrm{t}$ & $\begin{array}{l}1.44 \mathrm{~m} \\
1.64 \mathrm{~m}\end{array}$ & $\begin{array}{l}\text { la, } 1 \mathrm{~b}, 2 \mathrm{~b}, 3 \\
1 \mathrm{~b}, 1 \mathrm{~b}, 2,3\end{array}$ & $1,3,24$ \\
\hline 3 & 86.0 & d & $3.23 \mathrm{dd}(12,2)$ & $2 a, 2 b$ & $5,24,25,26$ \\
\hline 5 & 84.2 & $\mathrm{~d}$ & $3.15 \mathrm{dd}(12,2)$ & $6 a, 6 b$ & $3,6,10,27$ \\
\hline 6 & 26.2 & $\mathrm{t}$ & $\begin{array}{l}1.54 \mathrm{~m} \\
1.72 \mathrm{~m}\end{array}$ & $\begin{array}{l}5,6 \mathrm{~b}, 7 \mathrm{a}, 7 \mathrm{~b} \\
5,6 \mathrm{a}, 7 \mathrm{a}, 7 \mathrm{~b}\end{array}$ & 5,10 \\
\hline 7 & 38.4 & $\mathrm{t}$ & $\begin{array}{l}1.90 \mathrm{~m} \\
2.08 \mathrm{dt}(11.5,3)\end{array}$ & $\begin{array}{l}6 a, 6 b, 7 b \\
6 a, 6 b, 7 a\end{array}$ & $5,6,9,28$ \\
\hline 8 & 84.7 & $\mathrm{~s}$ & & & \\
\hline 9 & 52.8 & d & $1.69 \mathrm{~d}(10)$ & 11 & $5,10,11,12,28$ \\
\hline 10 & 37.7 & $\mathrm{~s}$ & & & \\
\hline 11 & 64.1 & d & $4.89 \mathrm{~d}(10)$ & 9 & $9,10,12,13,18$ \\
\hline 12 & 118.4 & $s$ & & & \\
\hline 13 & 152.8 & $\mathrm{~s}$ & & & \\
\hline 15 & 183.0 & s & & & \\
\hline 16 & 132.8 & $\mathrm{~s}$ & & & \\
\hline 17 & 157.3 & s & & & \\
\hline 17-OMe & 62.8 & $q$ & $4.01 \mathrm{~s}$ & & 17 \\
\hline $\begin{array}{l}18 \\
19\end{array}$ & $\begin{array}{l}185.5 \\
33.0\end{array}$ & $\begin{array}{l}\mathrm{S} \\
\mathrm{d}\end{array}$ & $3.38 \mathrm{~m}$ & 20,29 & $15,16,17,20,29$ \\
\hline 20 & 78.1 & d & 5.25 br d (10) & 19 & $\begin{array}{l}16,19,21,22,20- \\
\text { OCOMe, } 30\end{array}$ \\
\hline 20-OCOMe & 171.5 & s & & & \\
\hline 20-OCOMe & 22.0 & $\mathrm{q}$ & $1.88 \mathrm{~s}$ & & OCOMe \\
\hline 21 & 36.8 & $\mathrm{~d}$ & $1.69 \mathrm{~m}$ & 30 & 22,30 \\
\hline 22 & 28.1 & $\mathrm{t}$ & $\begin{array}{l}1.15 \mathrm{~m} \\
1.27 \mathrm{~m}\end{array}$ & $\begin{array}{l}22 \mathrm{~b}, 23 \\
22 \mathrm{a}, 23\end{array}$ & 21,30 \\
\hline $\begin{array}{l}23 \\
24\end{array}$ & $\begin{array}{l}12.9 \\
72.8\end{array}$ & $\begin{array}{l}q \\
s\end{array}$ & $0.91 \mathrm{t}(7.5)$ & $22 a, 22 b$ & 21,22 \\
\hline 25 & 27.0 & $q$ & $1.18 \mathrm{~s}$ & & $3,24,26$ \\
\hline 26 & 24.7 & $\mathrm{q}$ & $1.16 \mathrm{~s}$ & & $3,24,25$ \\
\hline 27 & 13.3 & $q$ & $1.00 \mathrm{~s}$ & & $5,9,10$ \\
\hline 28 & 21.9 & $q$ & $1.31 \mathrm{~s}$ & & $7,8,9$ \\
\hline 29 & 16.2 & $q$ & $1.19 \mathrm{~d}(7)$ & 19 & $16,19,20$ \\
\hline 30 & 13.1 & $q$ & $0.93 \mathrm{~d}(7)$ & 21 & $20,21,22$ \\
\hline
\end{tabular}

a Assignments based on COSY, multiplicity-edited HSQC and HMBC NMR data.

(broad, $\left.3521 \mathrm{~cm}^{-1}\right)$, ester $\left(1730 \mathrm{~cm}^{-1}\right)$ and carbonyl groups $\left(1660\right.$ and $1645 \mathrm{~cm}^{-1}$ ). The ${ }^{13} \mathrm{C}$ NMR spectrum of 1 (Table 2) showed 31 resolved peaks, which could be classified into seven methyl, one methoxyl, five methylene, three methines, four oxygenated methines and eleven quaternary carbons. The ${ }^{1} \mathrm{H}$ NMR spectrum of $\mathbf{1}$ (Table 2) displayed signals for four oxymethine groups $\left(\delta_{\mathrm{H}} 5.25, \mathrm{brd} ; 4.89, \mathrm{~d}\right.$; 3.23 , dd; 3.15 , dd), five methylene groups $\left(\delta_{\mathrm{H}} 1.4 \sim 2.5, \mathrm{~m}\right)$, one methoxy group $\left(\delta_{\mathrm{H}} 4.01, \mathrm{~s}\right)$ and eight methyl groups $\left(\delta_{\mathrm{H}} 0.91, \mathrm{t} ; 0.93, \mathrm{~d} ; 1.00, \mathrm{~s} ; 1.16, \mathrm{~s} ; 1.18, \mathrm{~s} ; 1.19, \mathrm{~d} ; 1.31, \mathrm{~s}\right.$; and $1.88, \mathrm{~s})$. These data were similar to that of cochlioquinone A (2) ${ }^{8 \sim 10)}$ except for the presence of a methoxy group and the absence of aromatic methine H-17 $\left(\begin{array}{ll}\delta_{\mathrm{H}} & 6.56\end{array}\right)$ present in cochlioquinone $\left.\mathrm{A}(\mathbf{2})^{8 \sim 10}\right)$. The placement of the methoxy at $\mathrm{C}-17$ was confirmed by the observation of a ${ }^{3} J$ (OMe to $\mathrm{C}-17$ ) correlation in HMBC NMR spectrum. This was also in accord with the observed carbon resonance of C-17 at $\delta_{\mathrm{C}} 157.3$ since it is $\alpha$ to both an oxygen and a carbonyl function. These observations supported the assignment of $\mathbf{1}$ as the 17-methoxy derivative of cochlioquinone $\mathrm{A}$.

Examination of the NMR data of compound 4 (Table 3) suggested that $\mathbf{4}$ was a cochlioquinone derivative related to epi-cochlioquinone A (5). The physico-chemical properties of 4 are given in Table 1. A molecular formula of $\mathrm{C}_{31} \mathrm{H}_{46} \mathrm{O}_{8}$ was determined for compound $\mathbf{4}$ on the basis of positive HR-ESIMS and ${ }^{13} \mathrm{C}$ NMR data, which was different to 5 by a $\mathrm{CH}_{2}$ unit. Comparison of ${ }^{1} \mathrm{H}$ and ${ }^{13} \mathrm{C}$ NMR data of 4 with 
Table 3. ${ }^{1} \mathrm{H}(500 \mathrm{MHz})$ and ${ }^{13} \mathrm{C}(125 \mathrm{MHz}) \mathrm{NM}$ data for $11-O$-methyl-epi-cochlioquinone $\mathrm{A}(4)$ in $\mathrm{CDCl}_{3}$.

\begin{tabular}{|c|c|c|c|c|c|}
\hline \multirow{2}{*}{$\begin{array}{l}\text { No. } \\
1\end{array}$} & \multicolumn{2}{|c|}{${ }^{13} \mathrm{C}(\delta, \mathrm{m}){ }^{\mathrm{a}}$} & \multirow{2}{*}{$\begin{array}{l}{ }^{1} \mathrm{H} \delta(\mathrm{m}, J \text { in } \mathrm{Hz}) \\
1.35 \mathrm{~m} \\
2.05 \mathrm{~m}\end{array}$} & \multirow{2}{*}{$\begin{array}{l}\operatorname{COSY} \\
1 \mathrm{~b}, 2 \mathrm{a}, 2 \mathrm{~b} \\
1 \mathrm{a}, 2 \mathrm{a}, 2 \mathrm{~b}\end{array}$} & \multirow{2}{*}{ 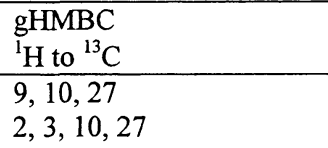 } \\
\hline & 37.7 & $\mathrm{t}$ & & & \\
\hline 2 & 22.7 & $t$ & $\begin{array}{l}1.48 \mathrm{~m} \\
1.62 \mathrm{~m}\end{array}$ & $\begin{array}{l}1 \mathrm{a}, 1 \mathrm{~b}, 2 \mathrm{~b}, 3 \\
1 \mathrm{a}, 1 \mathrm{~b}, 2 \mathrm{a}, 3\end{array}$ & $\begin{array}{l}10 \\
1,3,10,24\end{array}$ \\
\hline 3 & 85.2 & d & $3.15 \mathrm{dd}(12,2)$ & $2 a, 2 b$ & $1,5,24,25,26$ \\
\hline 5 & 84.2 & d & $3.08 \mathrm{dd}(12,2)$ & $6 a, 6 b$ & $1,3,6,27$ \\
\hline 6 & 24.5 & $\mathrm{t}$ & $\begin{array}{l}1.57 \mathrm{~m} \\
1.80 \mathrm{~m}\end{array}$ & $\begin{array}{l}5,6 b, 7 a \\
5,6 a\end{array}$ & $\begin{array}{l}5,10 \\
5,7\end{array}$ \\
\hline 7 & 37.5 & $\mathrm{t}$ & $\begin{array}{l}1.72 \mathrm{~m} \\
2.35 \mathrm{~m}\end{array}$ & $\begin{array}{l}6 a, 7 b \\
7 a\end{array}$ & $\begin{array}{l}6,8 \\
5,6,8,9\end{array}$ \\
\hline $\begin{array}{l}8 \\
9\end{array}$ & $\begin{array}{l}80.1 \\
53.4\end{array}$ & $\begin{array}{l}\mathrm{s} \\
\mathrm{d}\end{array}$ & $1.60 \mathrm{~d}(9)$ & 11 & $1,7,10,11,12,27$ \\
\hline $\begin{array}{l}10 \\
11\end{array}$ & 35.5 & s & & & $8,10,12,13,18,11-\mathrm{OMe}$ \\
\hline $11-\mathrm{OMe}$ & $\begin{array}{l}68.4 \\
57.9\end{array}$ & $\begin{array}{l}d \\
q\end{array}$ & $\begin{array}{l}4.08 \mathrm{~d}(9) \\
3.40 \mathrm{~s}\end{array}$ & 9 & $\begin{array}{l}8,10,12,13,18,11-0 \mathrm{Me} \\
11\end{array}$ \\
\hline & $\begin{array}{l}119.0 \\
153.3\end{array}$ & $\begin{array}{l}s \\
s\end{array}$ & & & \\
\hline 15 & 182.2 & $\mathrm{~s}$ & & & \\
\hline 16 & 150.0 & $\mathrm{~s}$ & & & \\
\hline 17 & 135.0 & d & $6.55 \mathrm{~s}$ & & $12,15,19$ \\
\hline $\begin{array}{l}18 \\
19\end{array}$ & $\begin{array}{l}187.0 \\
35.5\end{array}$ & $\begin{array}{l}\mathrm{s} \\
\mathrm{d}\end{array}$ & $3.20 \mathrm{~m}$ & 20,29 & $16,20,29$ \\
\hline 20 & 79.5 & $\mathrm{~d}$ & $5.02 \mathrm{dd}(8,4)$ & 19,21 & 16,20 -OCOMe, 21 \\
\hline 20-OCEOMe & 171.4 & $\mathrm{~s}$ & & & \\
\hline 20-OCOMe & 21.7 & $q$ & $1.93 \mathrm{~s}$ & & 20-OCOMe \\
\hline 21 & 37.0 & $\mathrm{~d}$ & $1.60 \mathrm{~m}$ & 30 & $19,2 \overline{3}$ \\
\hline 22 & 27.5 & $\mathrm{t}$ & $\begin{array}{l}1.10 \mathrm{~m} \\
1.27 \mathrm{~m}\end{array}$ & $\begin{array}{l}22 b, 23 \\
22 a, 23\end{array}$ & 30 \\
\hline 23 & 12.7 & $q$ & $0.89 \mathrm{t}(7)$ & $22 \mathrm{a}, 22 \mathrm{~b}$ & 21,22 \\
\hline 24 & 72.8 & $\mathrm{~s}$ & & & \\
\hline 25 & 24.6 & $q$ & $1.16 \mathrm{~s}$ & & $3,24,26$ \\
\hline 26 & 27.0 & $q$ & $1.18 \mathrm{~s}$ & & $3,24,25$ \\
\hline $\begin{array}{l}27 \\
28\end{array}$ & 12.7 & $\mathrm{q}$ & $\begin{array}{l}0.60 \mathrm{~s} \\
1.31 \mathrm{~s}\end{array}$ & & $\begin{array}{l}1,5,9,10 \\
7,8,9\end{array}$ \\
\hline $\begin{array}{l}28 \\
29\end{array}$ & $\begin{array}{l}27.3 \\
17.8\end{array}$ & $\begin{array}{l}q \\
q\end{array}$ & $\begin{array}{l}1.31 \mathrm{~s} \\
1.17 \mathrm{~d}(7)\end{array}$ & 19 & $\begin{array}{l}7,8,9 \\
16,19,20\end{array}$ \\
\hline 30 & 14.0 & $\mathrm{q}$ & $0.91 \mathrm{~d}(7)$ & 21 & $20,21,22$ \\
\hline
\end{tabular}

those of epi-cochlioquinone $\mathrm{A}(5)^{11)}$ revealed that 4 had a methyl ether group $\left(\delta_{\mathrm{H}} 3.40, \mathrm{~s} ; \delta_{\mathrm{C}} 57.9\right)$ in addition to the epi-cochlioquinone A (5) skeleton. The observation of an HMBC correlation from the methyl ether protons to $\delta_{\mathrm{C}}$ 68.4 allowed placement of the methyl ether group at C-11 and assignment of the structure of 4 as the 11-O-methyl derivative of epi-cochlioquinone A. The relative stereochemistry of H-11 was deduced to be $\alpha$ from the $J_{9 \alpha-11}$ value of $9 \mathrm{~Hz}$, which required $\mathrm{H}-11$ and $\mathrm{H}-9 \alpha$ to be in a cis-diaxial arrangement.

\section{Biological Activities}

17-Methoxycochlioquinone A (1), cochlioquinone A (2), isocochlioquinone $\mathrm{A}(3), 11-O$-methyl-epi-cochlioquinone
A (4) and epi-cochlioquinone A (5) were found to compete effectively with MIP- $1 \alpha$ for binding to human CCR5 with $\mathrm{IC}_{50}$ values of $100,11,50,7$ and $4 \mu \mathrm{M}$ respectively. Comparison of the activity of $\mathbf{2}$ and $\mathbf{3}$ suggested that the quinoid skeleton increased the activity of the cochlioquinones, while substitution of a methoxy group at $\mathrm{C}-17$ in 1 significantly decreased the activity compared to 2. The $\mathrm{IC}_{50}$ values $\mathbf{4}$ and $\mathbf{5}$ were similar to that of cochlioquinone A (2) $(11 \mu \mathrm{M})$, which has the same 12,13,15-trisubstituted quinone unit but different stereochemistry at C-8. Cochlioquinones family have been previously reported to inhibit NADH-ubiquinone reductase $^{10)}$ and acyl-CoA cholesterol acyltransferase ${ }^{11)}$. 


\section{Acknowledgments}

We would like to acknowledge A/Prof. LAI from the Department of Chemistry, National University of Singapore, for obtaining IR spectra and A/Prof. LoH for the use of the polarimeter. The financial support of GlaxoSmithKline, the Economic Development Board of Singapore and Institute of Molecular and Cell Biology are gratefully acknowledged.

\section{References}

1) Kedzierska, K.; S. M. Crowe, S. Turville \& A. L. CUNNINGHAM: The influence of cytokines, chemokines and their receptors on HIV-1 replication in monocytes and macropharges. Rev. Med. Virology 13: 39 $\dot{\sim} 56,2003$

2) Locatl, M. \& P. M. Murphy: Chemokines and chemokine receptors: biology and clinical relevance in inflammation and AIDS. Ann. Rev. Med. 50: 425 440, 1999

3) LEHNER, T.: The role of CCR5 chemokine ligands and antibodies to CCR5 coreceptors in preventing HIV infection. Trends in Immunology 23: 347 351, 2002

4) Kazmierski, W. M.; L. Boone, W. Lawrence, C. WATSON \& T. KENAKIN: CCR5 chemokine receptors: gatekeepers of HIV-1 infection. Current Drug Targets: Infectious Disorders 2: 265 278, 2002

5) De ClercQ, E.: New anti-HIV agents and targets. Med. Res. Rev. 22: 531 565, 2002
6) Yoganathan, K.; C. Rossant, S. Ng, Y. Huang, M. S. Butler \& A. D. Buss: 10-Methoxydihydrofuscin, fuscinarin and fuscin, novel antagonists of the human CCR5 receptor from Oidiodendron griseum. J. Nat. Prod. 66: 1116 1117, 2003

7) CaO, S.; C. Rossant, S. NG, A. D. Buss \& M. S. BUTLER: Phenolic derivatives from Wigandia urens active against the chemokine receptor CCR5. Phytochemistry 64: 987 990, 2003

8) Lim, C.-H.; H. Miyagawa, M. Akamatsu, Y. NaKagawa \& T. UENO: Structures and biological activities of phytoxins produced by the plant pathogenic fungus Bipolaris cynodontis cynA. J. Pesticide Sci. 23: 281 288, 1998

9) Miyagawa, H.; S. Nagai, T. Tsurushima, M. Sato, T. Ueno \& H. Fukami: Phytotoxins produced by the plant pathogenic fungus Bipolaris bicolor El-1. Biosci. Biotech. Biochem. 58: 1143 1145, 1994

10) Lim, C.-H.; H. Ueno, H. Miyoshi, H. Miyagawa, H. IWAMURA \&. T. UENo: Phytoxic compounds cochlioquinones are inhibitors of mitochondrial NADHubiquinone reductase. J. Pesticide Sci. 21: 213 215, 1996

11) Fujloka, T.; K. Yao, K. Hamano, T. Hosoya, T. Kagasaki, Y. Furukawa, H. Haruyama, S. Sato, T. Koga \& Y. TsuJIta: Epi-cochlioquinone A, a novel acylCoA: Cholesterol acyltranferase inhibitor produced by Stachybotrys bisbyi. J. Antibiotics 49: 409 413, 1996

12) Cook, N. D.: Drug Discovery Today 1: 287 295, 1996 